\title{
Common fixed points for an uncountable family of weakly contractive operators
}

\section{PARIN CHAIPUNYA and POOM KUMAM}

\begin{abstract}
.
In this paper, we consider some behavior concerning common fixed points of an uncountable family of operators. We apply here the concept of circular metric spaces, and the operators are assumed to satisfy different rates of weak contractivity. We show under certain assumptions that weakly contractive family have some strong relationships to its common selector in terms of their fixed points.
\end{abstract}

Acknowledgements. Mr. Parin Chaipunya was supported jointly by the Thailand Research Fund (TRF) and King Mongkuts University of Technology Thonburi (KMUTT) through the Royal Golden Jubilee Ph.D. Program (Grant No. PHD/0045/2555).

\section{REFERENCES}

[1] Berinde, V. and Păcurar, M., The role of the pompeiu-hausdorff metric in fixed point theory, Creat. Math. Inform., 22 (2013), No. 2, 35-42

[2] Chaipunya, P, Cho, J. C. and Kumam, P., On circular metric spaces and common fixed points for an infinite family of set-valued operators, Vietnam J. Math., 42 (2014), No. 2, 205-218

[3] Chaipunya, P. and Kumam, P., Topological aspects of circular metric spaces and some observations on the KKM property towards quasi-equilibrium problems, J. Inequal. Appl., 2013:9, 2013

[4] Dugundji, J., Topology. Series in Advanced Mathematics. Boston: Allyn and Bacon, Inc. XVI, 447 p. (1966)., 1966

[5] Espínola, R. and Kirk, W., Set-valued contractions and fixed points, Nonlinear Anal., Theory Methods Appl., Ser. A, Theory Methods, 54 (2003), No. 3, 485-494

[6] Espínola, R. and Petruşel, A., Existence and data dependence of fixed points for multivalued operators on gauge spaces, J. Math. Anal. Appl., 309 (2005), No. 2, 420-432

[7] Fang, J.-X. and Liu, X.-Y., Fixed point theorems for set-valued $\Phi$-generalized contractions on gauge spaces, Nonlinear Anal., Theory Methods Appl., Ser. A, Theory Methods, 69 (2008), No. 1, 201-207

[8] Frigon, M., Fixed point results for generalized contractions in gauge spaces and applications, Proc. Am. Math. Soc., 128 (2000), No. 10, 2957-2965

Theoretical and Computational SCience (TaCS) Center and Department of Mathematics SCIENCE LABORATORY BUILDING, FACULTY OF SCIENCE

King MONGKUTS UNIVERSITY OF TECHNOLOGY THONBURI (KMUTT)

126 PRACHA Uthit RoAd, BANG MOD, THUNG KHRU, BANGKOK 10140 THAILAND

E-mail address: parin.cha@mail.kmutt.ac.th, poom.kum@kmutt.ac.th

Received: 30.08.2014; In revised form: 02.03.2015; Accepted: 12.03 .2015

2010 Mathematics Subject Classification. 47H10, 47H09.

Key words and phrases. Common fixed point, weakly contractive operators, circular metric spaces.

Corresponding author: Poom Kumam; poom.kum@kmutt.ac.th 